\title{
Faktor Yang Mempengaruhi Hasil Belajar IPA
}

\section{Nyoman Dewi Astiti ${ }^{*}$, Luh Putu Putrini Mahadewi ${ }^{2}$, I Made Suarjana ${ }^{3}$}

1,2 Universitas Pendidikan Ganesha, Singaraja, Indonesia

\section{ART ICLE INFO}

Article history:

Received June 19, 2021

Revised June 20, 2021

Accepted July 30, 2021

Available online August 25, 2021

Kata Kunci:

Hasil Belajar, IPA

Keywords:

Learning Outcomes, Science Learning

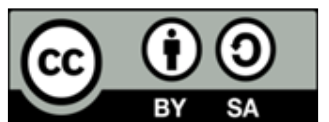

This is an open access article under the CC BY-SA license.

Copyright $(2021$ by Author. Published by Universitas Pendidikan Ganesha.

\section{A B S T RA CT}

\begin{abstract}
A B S T RA K
Masih rendahnya hasil belajar IPA siswa dan tidak sesuai dengan nilai kriterium ketuntasan minimum (KKM) serta kurangnya perhatian langsung dari guru ke siswa karena situasi di masa pembelajaran daring. Tujuan penelitian ini adalah untuk menganalisis hubungan faktor yang memengaruhi hasil belajar IPA siswa fokus pada gaya belajar siswa (visual, auditorial, kinestetik) dan pemanfaatan media belajar oleh guru. Jenis penelitian ini adalah penelitian expost-facto dengan menggunakan metode pengumpulan data berupa kuesioner/angket pada variabel gaya belajar dan pemanfaatan media belajar. Populasi dalam penelitian ini sebanyak 156 siswa dan jumlah sampel yang digunakan dalam penelitian sebanyak 132 siswa di kelas VI SD Gugus VI Kecamatan Gerokgak. Data dianalisis menggunakan analisis regresi sederhana dan analisis regresi berganda. Berdasarkan taraf signifikansi $5 \%=0,171$ diperoleh hasil analisis yaitu terdapat hubungan yang signifikan gaya belajar visual terhadap hasil belajar IPA dengan $\mathrm{rx}_{1} \mathrm{y}=0,364(13,3 \%)$, terdapat hubungan yang signifikan gaya belajar auditorial terhadap hasil belajar IPA dengan $\mathrm{rx}_{2} \mathrm{y}=0,467(21,9 \%)$, terdapat hubungan yang signifikan gaya belajar kinestetik terhadap hasil belajar IPA dengan $r_{3} \mathrm{y}=$ $0,458(21 \%)$, terdapat hubungan yang signifikan pemanfaatan media belajar terhadap hasil belajar IPA dengan $\mathrm{rx}_{4} \mathrm{y}=0,249(6,2 \%)$, terdapat hubungan yang signifikan gaya belajar visual, auditorial, kinestetik dan pemanfaatan media belajar terhadap hasil belajar IPA dengan $\mathrm{rx}_{1,2,3,4 \mathrm{y}}=$ $0,626(37,3 \%)$. Ini menunjukkan bahwa tinggi rendahnya hasil belajar IPA yang diperoleh siswa dapat dipengaruhi oleh faktor gaya belajar dan faktor pemanfaatan media belajar.
\end{abstract}

\begin{abstract}
The students' science learning outcomes are still low and not following the minimum completeness criteria (KKM) and the lack of direct attention from teachers to students because of the situation in the online learning period. The purpose of this study was to analyze the relationship of factors that influence students' science learning outcomes, focusing on students' learning styles (visual, auditory, kinesthetic) and the use of learning media by teachers. This type of research is ex post facto research using data collection methods in the form of a questionnaire/questionnaire on learning style variables and the use of learning media. The population in this study was 156 students and for the number of samples used in the study as many as 132 students in class VI SD Cluster VI Gerokgak District. Data were analyzed using simple regression analysis and multiple regression analysis. Based on the significance level of $5 \%=0.171$, the results of the analysis show that there is a significant relationship between visual learning styles and science learning outcomes with rx1y $=0.364$ (13.3\%), there is a significant relationship between auditory learning styles and science learning outcomes with rx2y= $0.467(21.9 \%)$, there is a significant relationship between kinesthetic learning styles and science learning outcomes with $r \times 3 y=0.458(21 \%)$, there is a significant relationship between the use of learning media and science learning outcomes with $r \times 4 y=0.249(6.2 \%)$, there is a significant relationship which is significant for visual, auditory, kinesthetic learning styles and the use of learning media on science learning outcomes with $r \times 1,2,3,4 y=0.626$ (37.3\%). So that the high and low science learning outcomes obtained by students can be influenced by learning style factors and learning media utilization factors.
\end{abstract}




\section{PENDAHULUAN}

Pembelajaran saat ini menerapkan sistem pembelajaran daring (dalam jaringan) yang merupakan sistem pembelajaran tanpa tatap muka secara langsung antara guru dan siswa tetapi dilakukan melalui online yang membutuhkan jaringan internet. Guru harus memastikan kegiatan belajar mengajar tetap berjalan meskipun siswa belajar di rumah. Solusinya, guru dituntut dapat mendesain media pembelajaran sebagai inovasi dengan memanfaatkan media daring (online). Guru diminta kreatif dan inovatif dalam melaksanakan proses pembelajaran. Pembelajaran di sekolah dasar umumnya terdiri atas beberapa mata pelajaran, salah satunya adalah mata pelajaran IPA. IPA merupakan mata pelajaran mengenai kehidupan makhluk hidup yang ada di alam dan segala isinya dalam berbagai aktivitas kehidupan (Dewi et al., 2019; Tesi Muskania \& Wilujeng, 2017). IPA salah satu muatan pelajaran yang sangat penting dan selalu diberikan pada setiap jenjang pendidikan. Pembelajaran IPA di sekolah dasar diorientasikan pada aktivitas peserta didik dan pendidik yang mendukung konsep, prisip serta prosedur yang dapat mendorong tercapainya tujuan pembelajaran bermakna dalam memperoleh hasil yang memuaskan (Ariyanto, 2016). Siswa secara aktif mencari dan menemukan pengetahuan, memiliki semangat yang tinggi dengan membuktikan sendiri kebenaran suatu teori serta dapat menerapkan konsep pembelajaran IPA dalam kehidupan sehari-hari (Novitawati \& Elyanoor, 2015). Pembelajaran IPA tidak hanya berfokus pada ranah kognitif, melainkan juga ranah afektif dan psikomotor sebagai aspek penilaian hasil belajar yang telah diperoleh oleh siswa. Hasil belajar siswa dipengaruhi oleh dua faktor yaitu faktor internal dan faktor eksternal (Pingge \& Wangid, 2016; Raresik et al., 2016).

Faktor internal yang dapat mempengaruhi hasil belajar adalah faktor yang berasal dari diri siswa yang meliputi kecerdasan, sikap, kebiasaan, bakat, minat, dan motivasi. Faktor yang berasal dari luar diri siswa disebut dengan faktor eksternal yang meliputi keluarga, masyarakat, dan sekolah. Salah satu faktor internal yang memengaruhi hasil belajar siswa, yaitu gaya belajar yang dimiliki oleh siswa. Gaya belajar yang dimiliki setiap siswa umumnya berbeda. Oleh karena itu, penting bagi siswa dalam mengenal gaya belajar dan ketepatan penggunaan gaya belajar. Dengan demikian, siswa tidak akan kesulitan atau mendapat kendala dalam memahami, menerima, dan mengolah informasi pada saat proses belajar. Selain faktor internal, terdapat juga faktor eksternal yang dapat memengaruhi hasil belajar siswa, yaitu salah satunya pemanfaatan media belajar. Media belajar adalah alat yang digunakan dalam proses belajar yang dapat membantu siswa, sehingga makna pesan yang disampaikan jelas dan tujuan pembelajaran dapat tercapai dengan baik (Nurrita, 2018; Rasam \& Sari, 2018). Proses pembelajaran akan lebih bermakna apabila siswa dapat melihat, menyentuh, dan mengalami sendiri media yang dimanfaatkan oleh guru. Ketepatan dan penggunaan media belajar akan sangat berpengaruh terhadap hasil belajar siswa (Ekayani; Astuti et al., 2017; Audie, 2019). Dengan demikian, kreativitas guru dalam memanfaatkan media belajar pada saat proses pembelajaran akan berpengaruh terhadap pencapaian hasil belajar siswa yang optimal.

Namun kenyataannya, gaya belajar dan pemanfaatan media belajar di lapangan tidaklah demikian. Berdasarkan hasil wawancara bersama guru ditemukan beberapa permasalahan, yaitu 1) guru tidak mengenal gaya belajar yang dimiliki oleh siswa. Hal ini disebabkan oleh keterbatasan guru dalam memberikan perhatian kepada siswa ketika pembelajaran daring; 2) siswa tidak mengenali gaya belajar dirinya. Hal ini disebabkan oleh keterbatasan orang tua dalam memberikan pengawasan pada saat anak belajar di rumah; 3) guru jarang memanfaatkan media pembelajaran dan hanya menggunakan bahan ajar yang ada pada buku paket siswa, sehingga siswa mengalami kesulitan memahami materi pembelajaran yang diberikan; 4) siswa tidak mengerjakan tugas yang diberikan dengan baik karena tidak memiliki keberanian bertanya dan ketidaksesuaian gaya belajar, sehingga kurang menguasai materi yang diberikan oleh guru; dan 5) terdapat beberapa siswa yang memperoleh hasil belajar IPA masih kurang dari nilai KKM. Hasil penilaian tengah semester IPA siswa kelas VI dapat dilihat pada Tabel 1.

Tabel 1. Nilai PTS IPA Siswa Kelas VI SD Gugus VI Kecamatan Gerokgak

\begin{tabular}{llllllll}
\hline \multirow{2}{*}{ No. } & \multirow{2}{*}{ Nama Sekolah } & \multirow{2}{*}{$\begin{array}{c}\text { Jumlah } \\
\text { Siswa }\end{array}$} & \multirow{2}{*}{ KKM } & \multicolumn{3}{c}{ Jumlah } \\
\cline { 6 - 8 } & & & & T & T (\%) & TT & \multicolumn{1}{c}{ TT (\%) } \\
\hline 1 & SD Negeri 1 Pemuteran & 25 & 75 & 20 & $80 \%$ & 5 & $20 \%$ \\
2 & SD Negeri 2 Pemuteran & 39 & 73 & 32 & $82,05 \%$ & 7 & $17,95 \%$ \\
3 & SD Negeri 3 Pemuteran & 36 & 70 & 32 & $88,89 \%$ & 4 & $11,11 \%$ \\
4 & SD Negeri 4 Pemuteran & 33 & 60 & 33 & $100 \%$ & 0 & $0 \%$ \\
5 & SD Negeri 5 Pemuteran & 23 & 65 & 21 & $91,30 \%$ & 2 & $8,70 \%$ \\
\hline & Jumlah & $\mathbf{1 5 6}$ & & $\mathbf{1 3 8}$ & $\mathbf{8 8 , 8 4 \%}$ & $\mathbf{1 8}$ & $\mathbf{1 1 , 5 6 \%}$ \\
\hline
\end{tabular}

Berdasakan data yang disajikan pada Tabel 1, diketahui bahwa terdapat beberapa siswa yang memperoleh hasil belajar belum memenuhi nilai kriterium ketuntasan minimum (KKM). Hal ini 
disebabkan oleh luasnya materi pembelajaran IPA serta kecenderungan siswa menghafa materil, sehingga siswa malas belajar dan tidak mengerjakan tugas dengan baik. Adanya masalah kurangnya perhatian terhadap gaya belajar yang dimiliki siswa pada saat proses belajar dan jarangnya pemanfaatan media belajar oleh guru juga dapat mengakibatkan hasil belajar IPA siswa berada di bawah nilai KKM. Apabila masalah yang ada dibiarkan terus menerus, maka akan berdampak pada hasil belajar siswa yang rendah dan tujuan pembelajaran menjadi kurang optimal.

Kita ketahui bahwa gaya belajar dan pemanfaatan media belajar merupakan salah satu faktor yang dapat mempengaruhi hasil belajar siswa (Hanifah \& Mulyaningrum, 2021; Masturah et al., 2018; Prabanitha et al., 2020; Putri Ningrat et al., 2018; Utami \& Gafur, 2015). Salah satu upaya yang dapat dilakukan adalah dengan cara guru melakukan pendekatan kepada siswa dalam mengenal gaya belajar masing-masing siswa. Guru dapat memberikan perhatian pada saat belajar dan memanfaatkan media belajar sebagai perantara dalam memudahkan siswa memahami materi pelajaran, lebih ditingkatkan lagi pengawasan orang tua ketika anak belajar di rumah, dan bagi kepala sekolah mendukung ketersediaan sarana dan prasarana media pembelajaran. Gaya belajar dan pemanfaatan media belajar merupakan salah satu faktor yang dapat memengaruhi hasil belajar siswa. Gaya belajar merupakan kebiasaan yang disenangi atau cara yang dimiliki oleh individu dalam menerima, mengolah, dan menyerap informasi yang diberikan pada saat belajar (Amin \& Suardiman, 2016; Cholifah et al., 2016). Media belajar merupakan alat yang digunakan dan dimanfaatkan oleh guru dalam memberikan informasi sebagai bentuk pesan atau isi materi pelajaran kepada siswa, sehingga mempermudah dalam penyampaian materi pelajaran (Fauyan, 2019; Hartini et al., 2017; Herayanti et al., 2017). Apabila siswa tidak mengenali gaya belajar dirinya, maka siswa akan mengalami kesulitan dalam menyerap materi pelajaran.n Selain itu, apabila guru juga kurang memperhatikan gaya belajar siswa dan jarang memanfaatan media belajar pada saat proses belajar, maka akan berpengaruh terhadap hasil belajar siswa. Tujuan penelitian ini adalah untuk menganalisis hubungan faktor gaya belajar dan pemanfaatan media belajar terhadap hasil belajar IPA.

\section{METODE}

Penelitian ini bertujuan mengetahui hubungan antara gaya belajar siswa dan pemanfaatan media belajar terhadap hasil belajar IPA, dengan tidak memanipulasi atau menggali fakta yang sudah terjadi sebelumnya, sehingga penelitian ini termasuk penelitian expost-facto yaitu suatu penelitian empiris dan sistematis. Adapun variabel bebas dalam penelitian ini yaitu gaya belajar visual, gaya belajar auditorial, gaya belajar kinestetik, dan pemanfaatan media belajar, sedangkan hasil belajar IPA menjadi variable terikat. Rancangan penelitian ini dapat dilihat pada Gambar 1.
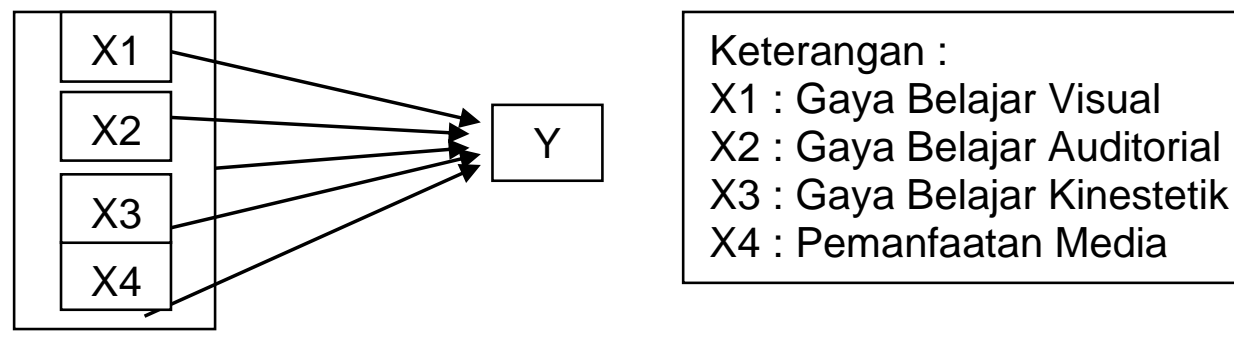

Gambar 1. Rancangan Penelitian

Populasi dalam penelitian ini adalah keseluruhan siswa kelas VI SD Gugus VI Kecamatan Gerokgak yang berjumlah 156 siswa. Pengambilan sampel menggunakan teknik Simple Random Sampling. Untuk menentukan ukuran sampel dalam penelitian ini menggunakan tabel menurut Morgan dan Krecjie, dalam menentukan jumlah sampel diambil dari populasi secara random dengan tingkat ketelitian $95 \%$ dan taraf sigifikansi 5\% untuk estimasi formasi populasi (Agung, 2014). Berdasarkan hal tersebut, dari populasi 156 siswa diperoleh hasil sebanyak 106 sampel minimal yang harus diteliti. Untuk mengatasi beberapa hal yang kemungkinan terjadi pada saat penyebaran instrument kepada subjek penelitian, maka dilakukan penambahan jumlah sampel minimal dengan menggunakan Formula Warwick dan lininger. Sehingga perolehan jumlah sampel sebanyak 132 siswa dari jumlah populasi. Penelitian ini menggunakan dua teknik dalam pengumpulan data yaitu skor hasil belajar siswa diperoleh melalui pencatatan dokumen serta skor gaya belajar dan pemanfaatan media belajar diperoleh melalui angket/kuesioner berbentuk data kuantitatif serta berbentuk data interval dengan menggunakan skala likert. Adapun kisi-kisi 
kuesioner gaya belajar siswa dan pemanfaatan media belajar akan dijabarkan pada Tabel 2 dan Tabel 3 berikut ini.

Tabel 2. Kisi-Kisi Kuesioner Gaya Belajar

\begin{tabular}{|c|c|c|c|c|c|}
\hline \multirow[t]{2}{*}{ Variabel } & \multirow{2}{*}{$\begin{array}{l}\text { Sub } \\
\text { Variabel }\end{array}$} & \multirow[t]{2}{*}{ Indikator } & \multirow{2}{*}{$\begin{array}{l}\text { Jumlah } \\
\text { Item }\end{array}$} & \multicolumn{2}{|c|}{ No Item } \\
\hline & & & & $(+)$ & $(-)$ \\
\hline Gaya & Gaya Belajar & Belajar dengan cara visual & 7 & $1,2,3,5,6$ & 4,7 \\
\hline \multirow[t]{15}{*}{$\begin{array}{l}\text { Belajar } \\
\text { Siswa }\end{array}$} & Visual & $\begin{array}{l}\text { Mengerti baik mengenai posisi, } \\
\text { bentuk, angka, dan warna }\end{array}$ & 7 & $8,9,10,13,14$ & 11,12 \\
\hline & & Rapi dan teratur & 7 & $\begin{array}{l}15,16,19 \\
20\end{array}$ & $\begin{array}{l}17,18 \\
21\end{array}$ \\
\hline & & $\begin{array}{l}\text { Tidak terganggu dengan } \\
\text { keributan }\end{array}$ & 5 & $22,23,24,25$ & 26 \\
\hline & & Sulit menerima instruksi verbal & 4 & $27,28,30$ & 29 \\
\hline & Gaya Belajar & Belajar dengan cara mendengar & 7 & $1,2,3,4,6,7$ & 5 \\
\hline & Auditorial & Baik dalam aktivitas lisan & 5 & $8,10,12$ & 9,11 \\
\hline & & $\begin{array}{l}\text { Memiliki kepekaan terhadap } \\
\text { musik }\end{array}$ & 7 & $14,15,16,18$ & $13,17,19$ \\
\hline & & $\begin{array}{l}\text { Mudah terganggu dengan } \\
\text { keributan }\end{array}$ & 5 & $20,22,23$ & 21,24 \\
\hline & & Lemah dalam aktivitas visual & 6 & $25,26,27,28$ & 29,30 \\
\hline & Gaya Belajar & Belajar dengan aktivitas fisik & 5 & $1,2,3,5$ & 4 \\
\hline & Kinestetik & $\begin{array}{l}\text { Peka terhadap ekspresi dan } \\
\text { bahasa tubuh }\end{array}$ & 6 & $6,7,9,11$ & 8,10 \\
\hline & & $\begin{array}{l}\text { Berorientasi pada fisik dan } \\
\text { banyak gerak }\end{array}$ & 6 & $12,13,14,1517$ & 16 \\
\hline & & Suka coba-coba dan kurang rapi & 6 & $18,20,21$ & $19,22,23$ \\
\hline & & Lemah dalam aktivitas verbal & 7 & $24,25,26,29,30$ & 27,28 \\
\hline & & Jumlah & 90 & 61 & 29 \\
\hline
\end{tabular}

Tabel 3. Kisi-Kisi Kuesioner Pemanfaatan Media Belajar

\begin{tabular}{clccc}
\hline \multirow{2}{*}{ No. Indikator } & & Jumlah & \multicolumn{2}{c}{ No Item } \\
\cline { 3 - 5 } & & Item & $\mathbf{( + )}$ & $\mathbf{( - )}$ \\
\hline 1 & Guru dapat menarik perhatian siswa & 3 & 1,2 & 3 \\
2 & Guru menggunakan media yang bervariasi saat mengajar & 2 & 4,5 & - \\
3 & Siswa mudah mengakses media pembelajaran yang diberikan guru & 3 & 6 & 7,8 \\
4 & Guru menggunakan media sesuai dengan materi yang diajarkan ke & 3 & 9,10 & 11 \\
& Siswa & & & 12 \\
5 & Guru menggunakan metode dan strategi mengajar yang bervariasi & 2 & 12 & 13 \\
6 & Guru mengevaluasi pembelajaran pada akhir jam pembelajaran & 3 & 14,15 & 16 \\
7 & Guru menjadi hemat waktu dan tenaga dalam proses belajar & 3 & 17,18 & 19 \\
8 & Siswa mudah memahami dan menangkap materi pelajaran yang & 2 & 20,21 & - \\
& diberikan & & & \\
9 & Siswa menjadi lebih aktif & 3 & 22,23 & 24 \\
10 & Siswa tidak bosan menerima materi pelajaran & 2 & 25,26 & - \\
11 & Menghilangkan verbalisme siswa & 2 & 27 & 28 \\
12 & Siswa mengetahui SK dan indikator pembelajaran & 2 & 29 & 30 \\
\hline & $\quad$ Jumlah & $\mathbf{3 0}$ & $\mathbf{2 0}$ & $\mathbf{1 0}$ \\
\hline
\end{tabular}

Sebelum penyebaran kuesioner kepada responden dimasing-masing sekolah, terlebih dahulu dilakukan uji judges dengan menggunakan rumus Conten Validity. Kemudian dilanjutkan dengan mencari validitas butir dan reliabilitas. Berdasarkan hasil reliabilitas keempat variabel dinyatakan reliabel karena hasil yang diperoleh pada uji reliabilitas gaya belajar visual 0,72 >0,25, hasil yang diperoleh pada uji reliabilitas gaya belajar auditorial $0,43>0,26$, hasil yang diperoleh pada uji reliabilitas gaya belajar kinestetik 0,61 >0,26, dan hasil yang diperoleh pada uji reliabilitas pemanfaatan media belajar 0,78> 0,26 . Teknik analisis statistik yang digunakan dalam penelitian ini yaitu analisis statistik deskriptif dan analisis statistik inferensial dengan menggunakan bantuan IBM SPSS Statistics 17.0. Pada analisis statistik inferensial dilakukan uji prasyarat analisis dan uji hipotesis dengan menggunakan analisis regresi 
sederhana dan analisis regresi berganda. Berikut ringkasan hasil uji ahli (judges) terhadap instrument kuesioner gaya belajar dan pemanfaatan media belajar yang disajikan pada tabel 4.

Tabel 4. Hasil Uji Judges Gaya Belajar dan Pemanfaatan Media Belajar

\begin{tabular}{lccccc}
\hline \multirow{2}{*}{ Variabel } & \multicolumn{2}{c}{ Penilai 1 } & \multicolumn{2}{c}{ Penilai 2 } & \multirow{2}{*}{ Kategori } \\
\cline { 2 - 4 } & KR & SR & KR & SR & Validitas \\
\hline Gaya Belajar Visual & 2 & 28 & 2 & 28 & Sangat Tinggi \\
Gaya Belajar Auditorial & 1 & 29 & 4 & 26 & Sangat Tinggi \\
Gaya Belajar Kinestetik & 2 & 28 & 0 & 30 & Sangat Tinggi \\
Pemanfaatan Media Belajar & 0 & 30 & 0 & 30 & Sangat Tinggi \\
\hline
\end{tabular}

Keterangan:

$\mathrm{SR}=$ Sangat Relevan

$\mathrm{KR}=$ Kurang Relevan

\section{HASIL DAN PEMBAHASAN}

Hasil

Analisis data yang diperoleh dalam penelitian ini berupa skor yang didapat dari penyebaran kuesioner gaya belajar dan kuesioner pemanfaatan media belajar. Sedangkan hasil belajar IPA didapat dari hasil pencatatan dokumen penilaian tengah semester (PTS) di Gugus VI Kecamatan Gerokgak. Berdasarkan hasil analisis statistik deskriptif, maka diperoleh skor rata-rata gaya belajar visual 106,14 berada pada predikat baik, skor rata-rata gaya belajar auditorial 92,67 berada pada predikat baik, skor rata-rata gaya belajar kinestetik 97,93 berada pada predikat baik, skor rata-rata pemanfaatan media belajar 109,64 berada pada predikat baik, dan skor rata-rata hasil belajar IPA 76,00 berada pada predikat sangat baik. Tipe gaya belajar berdasarkan data hasil analisis deskriptif diperoleh data gaya belajar yang umumnya berada pada tipe gaya belajar visual sebanyak 98 siswa, gaya belajar auditorial sebanyak 6 siswa, gaya belajar kinestetik sebanyak 19 siswa, dan gaya belajar campuran sebanyak 9 siswa. Siswa dengan tipe gaya belajar visual lebih banyak dibandingkan dengan gaya belajar auditorial dan gaya belajar kinestetik, Hal ini disebabkan oleh kebiasaan-kebiasaan yang memang sering dilakukan oleh siswa dalam kehidupan sehari-hari. Gaya belajar visual menekankan pada aspek penglihatan dalam mengolah dan menyerap informasi ketika belajar. Siswa dengan gaya belajar visual mudah mengingat suatu konsep atau materi pembelajaran dengan pengoptimalan kemampuan penglihatan.

Untuk mengetahui hubungan antara variabel bebas dan variabel terikat yang digunakan dalam penelitian ini, maka dilakukan pengujian hipotesis dengan uji regresi sederhana dan uji regresi berganda. Sebelum dilakukan uji hipotesis terlebih dahulu dilakukan uji prasyarat analisis yang harus memenuhi prasyarat berupa uji normalitas, uji liniearitas, uji multikoliniearitas, uji heterokedastisitas, dan uji autokorelasi. Perhitungan uji hipotesis dan uji prasyarat analisis menggunakan bantuan IBM SPSS Statistics 17.0. Hasil dari perhitungan data dan uji signifikansi normalitas sebaran data dengan menggunakan uji Kolmogorov-Smirnov (K-S) disajikan pada Tabel 5, sebagai berikut.

Tabel 5. Hasil Uji Normalitas Sebaran Data

\begin{tabular}{llll}
\hline \multicolumn{1}{c}{ Unit Analisis } & \multicolumn{2}{c}{ Kolmogorov-Smirnov (K-S) } \\
\cline { 2 - 4 } & Statistics & N. & Sig. \\
\hline Gaya Belajar Visual & 0,083 & 132 & 0,328 \\
Gaya Belajar Auditorial & 0,076 & 132 & 0,428 \\
Gaya Belajar Kinestetik & 0,075 & 132 & 0,450 \\
Pemanfaatan Media Belajar & 0,087 & 132 & 0,277 \\
Hasil Belajar IPA & 0,115 & 132 & 0,060 \\
\hline
\end{tabular}

Berdasarkan data yang diperoleh pada Tabel 5 di atas, hasil uji normalitas dengan menggunakan bantuan IBM SPSS Statistics 17.0 diperoleh nilai Asymp.Sig (2-tailed) > 0,05, sehingga dapat disimpulkan bahwa variabel gaya belajar visual, gaya belajar auditorial, gaya belajar kinestetik, pemanfaatan media belajar, dan hasil belajar IPA berdistribusi normal. Selanjutnya dilakukan uji liniearitas pada variabel yang digunakan dalam penelitian ini yang bertujuan untuk mengetahui bentuk hubungan antara variabel terikat dan setiap variabel bebas. Adapun hasil penghitungan uji liniearitas data dengan menggunakan Test Of Liniearty disajikan pada Tabel 6 sebagai berikut. 
Tabel 6. Hasil Uji Liniearitas

\begin{tabular}{lllllc}
\hline \multicolumn{1}{c}{ Unit Analisis } & \multicolumn{4}{c}{ Test Of Liniearty } \\
\cline { 2 - 6 } & $\begin{array}{l}\text { Sum of } \\
\text { Squares }\end{array}$ & Df & $\begin{array}{l}\text { Mean } \\
\text { Square }\end{array}$ & F & Sig. \\
\hline Gaya Belajar Visual dan Hasil Belajar & 518,819 & 32 & 16,213 & 1,018 & 0,456 \\
Gaya Belajar Auditorial dan Hasil Belajar & 478,717 & 31 & 15,442 & 1,096 & 0,357 \\
Gaya Belajar Kinestetik dan Hasil Belajar & 529,970 & 33 & 16,060 & 1,141 & 0,304 \\
Pemanfaatan Media Belajar dan Hasil Belajar & 584,733 & 39 & 14,993 & 0,820 & 0,753 \\
\hline
\end{tabular}

Berdasarkan data yang diperoleh pada Tabel 6 di atas, hasil uji liniearitas dengan menggunakan bantuan IBM SPSS Statistics 17.0 diperoleh nilai Sig. Deviation Of Linearty > 0,05, maka dapat disimpulkan bahwa terdapat hubungan liniear di antara variabel bebas terhadap variabel terikat. Selanjutnya dilakukan pengujian multikolinearitas data yang bertujuan menguji dan menentukan ada atau tidaknya hubungan antar variabel bebas dan variabel terikat dengan ketentuan nilai VIF di sekitar angka 1 atau memiliki Tolerance mendekati 1, maka tidak terdapat masalah multikolinearitas dalam regresi. Hasil dari penghitungan dan uji multikolinearitas data dengan Collinearty Statistics disajikan pada Tabel 7 sebagai berikut.

Tabel 7. Hasil Uji Multikolinearitas

\begin{tabular}{lcc}
\hline \multicolumn{1}{c}{ Unit Analisis } & \multicolumn{2}{c}{ Collinearty Statistics } \\
\cline { 2 - 3 } & Tolerance & 1,119 \\
\hline Gaya Belajar Visual & 0,894 & 1,182 \\
Gaya Belajar Auditorial & 0,846 & 1,256 \\
Gaya Belajar Kinestetik & 0,796 & 1,052 \\
Pemanfaatan Media Belajar & 0,950 & . \\
\hline
\end{tabular}

Berdasarkan data yang diperoleh pada Tabel 7 di atas, uji multikolinearitas dengan menggunakan bantuan IBM SPSS Statistics 17.0 diperoleh analisis gaya belajar dan pemanfaatan media belajar nilai Tolerance mendekati angka 1 atau berada di atas 0,10 dan nilai VIF di sekitar angka 1 atau kurang dari 10, sehingga dapat disimpulkan bahwa tidak terjadi multikolinearitas antar variabel bebas dan variabel terikat. Selanjutnya dilakukan pengujian heterokedastisitas data dalam penelitian ini, data regresi yang baik biasanya tidak terjadi heterokedastisitas apabila titik-titik atau bulatan pada gambar menyebar ke atas dan ke bawah sumbu Y tanpa membentuk pola tertentu, maka tidak terjadi heterokedastisitas. Uji heterokedastisitas menggunakan metode Scatersplots yang disajikan pada Gambar 2 sebagai berikut.

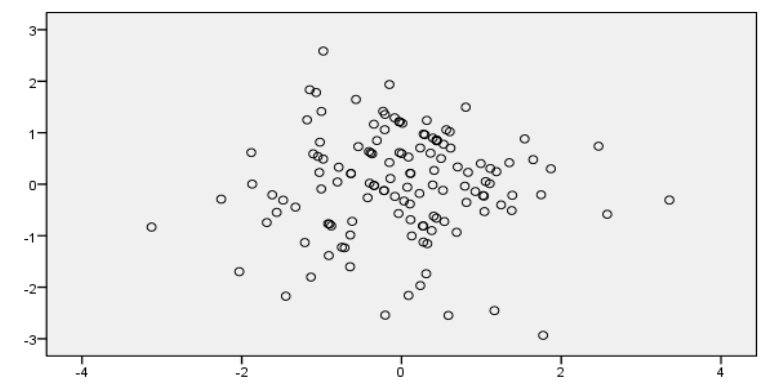

Gambar 2. Hasil Uji Heterokedastisitas

Berdasarkan data yang diperoleh pada Gambar 2 di atas, hasil uji heterokedastisitas dengan menggunakan bantuan IBM SPSS Statistic 17.0 menunjukkan bahwa titik-titik atau bulatan pada grafik menyebar ke atas dan ke bawah sumbu Y tanpa membentuk pola tertentu, maka dapat diketahui bahwa tidak terjadi heterokedastisitas dan regresi yang baik dapat terpenuhi. Selanjutnya dilakukan uji autokorelasi yang digunakan untuk mengetahui ada atau tidaknya penyimpangan asumsi dengan menggunakan analisis uji Durbin Watson mendekati nilai 2, maka dapat dinyatakan seluruh kelompok data tidak terjadi autokorelasi. Hasil dari penghitungan data dan uji autokorelasi disajikan pada Tabel 8 sebagai berikut. 
Tabel 8. Hasil Uji Autokorelasi

\begin{tabular}{|c|c|c|c|c|c|}
\hline Model & $\boldsymbol{R}$ & R Square & $\begin{array}{l}\text { Adjusted } R \\
\text { Square }\end{array}$ & $\begin{array}{l}\text { Std. Error of the } \\
\text { Estimate }\end{array}$ & Durbin-Watson \\
\hline 1 & $0,626^{a}$ & 0,392 & 0,373 & 3,388 & 2,162 \\
\hline
\end{tabular}

Berdasarkan data yang diperoleh pada Tabel 8 di atas, diperoleh hasil uji autokorelasi dengan menggunakan bantuan IBM SPSS Statistics 17.0 yang menunjukkan bahwa koefisien Durbin Watson bernilai 2,162, maka dapat diketahui bahwa regresi variabel gaya belajar visual ( $\mathrm{X}_{1}$ ), gaya belajar auditorial $\left(\mathrm{X}_{2}\right)$, gaya belajar kinestetik $\left(\mathrm{X}_{4}\right)$, dan pemanfaatan media belajar $\left(\mathrm{X}_{4}\right)$ terhadap hasil belajar IPA (Y) tidak terjadi autokorelasi. Setelah keseluruhan uji analisis prasyarat terpenuhi, selanjutnya dilakukan uji hipotesis. Uji hipotesis yang digunakan pada penelitian ini adalah uji regresi sederhana berlaku pada hipotesis pertama-keempat dan uji regresi berganda pada hipotesis kelima dengan menggunakan bantuan IBM SPSS Statistics 17.0. Apabila perolehan $\mathrm{F}_{\text {hitung }}>\mathrm{F}_{\text {tabel }}$ maka $\mathrm{F}$ regresi signifikan. Kekuatan hubungan antara variabel bebas $(\mathrm{X})$ terhadap variabel terikat $(\mathrm{Y})$ ditunjukkan oleh koefisien korelasi $\left(\mathrm{r}_{\mathrm{xy}}\right)$ dengan kriteria $r_{\text {hitung }} \geq r_{\text {tabel. }}$. Hasil dari uji hipotesis secara keseluruhan dapat dilihat pada Tabel 9 sebagai berikut.

Tabel 9. Ringkasan Hasil Uji Hipotesis I, II, III, IV, dan V

\begin{tabular}{|c|c|c|c|c|c|c|c|c|c|}
\hline $\begin{array}{l}\text { Unit } \\
\text { Analisis }\end{array}$ & $R$ & $\begin{array}{l}R \\
\text { Square }\end{array}$ & $\begin{array}{l}\text { Adjusted } \\
\text { R Square }\end{array}$ & $\begin{array}{l}\text { Std. Error } \\
\text { of the } \\
\text { Estimate }\end{array}$ & $\begin{array}{l}\text { Sum of } \\
\text { Square }\end{array}$ & $D f$ & $\begin{array}{l}\text { Mean } \\
\text { Square }\end{array}$ & $\boldsymbol{F}$ & Sig. \\
\hline $\mathrm{X}_{1} \mathrm{Y}$ & 0,364 & 0,133 & 0,126 & 4,00008 & 317,912 & 1 & 317,912 & 19,869 & 0,000 \\
\hline $\mathrm{X}_{2} \mathrm{Y}$ & 0,467 & 0,219 & 0,213 & 3,79670 & 524,060 & 1 & 524,060 & 36,355 & 0,000 \\
\hline $\mathrm{X}_{3} \mathrm{Y}$ & 0,458 & 0,210 & 0,204 & 3,81768 & 503,295 & 1 & 503,295 & 34,532 & 0,000 \\
\hline $\mathrm{X}_{4} \mathrm{Y}$ & 0,249 & 0,062 & 0,055 & 4,159 & 149,086 & 1 & 149,086 & 8,618 & 0,004 \\
\hline $\mathrm{X}_{(1,2,3,4)} \mathrm{Y}$ & 0,626 & 0,392 & 0,373 & 3,388 & 939,860 & 4 & 234,965 & 20,465 & 0,000 \\
\hline
\end{tabular}

Berdasarkan data yang diperoleh pada Tabel 9 di atas, nilai $F_{h i t u n g}$ dari $X_{1} Y=19,869 ; X_{2} Y=36,355$; $\mathrm{X}_{3} \mathrm{Y}=34,532 ; \mathrm{X}_{4} \mathrm{Y}=8,618$; dan $\mathrm{X}_{(1,2,3,4)} \mathrm{Y}=20,465$. Dapat dilihat bahwa $F_{h i t u n g}$ lebih besar dari $\mathrm{F}_{\text {tabel }}$ pada taraf signifikansi $5 \%=2,44$. Maka dapat disimpulkan bahwa $\mathrm{F}$ regresi tersebut dinyatakan signifikan. Diperoleh besar kontribusi gaya belajar visual terhadap hasil belajar IPA sebesar 0,364, kontribusi gaya belajar auditorial terhadap hasil belajar IPA sebesar 0,467, kontribusi gaya belajar kinestetik terhadap hasil belajar IPA 0,458, kontribusi pemanfaatan media belajar terhadap hasil belajar IPA sebesar 0,249, dan kontribusi gaya belajar visual, auditorial, kinestetik dan pemanfaatan media belajar terhadap hasil belajar IPA sebesar 0,626. Uji signifikansi koefisien korelasi menggunakan tabel r Product Moment untuk n = 132 pada taraf signifikansi 5\%. Nilai rtabel untuk nilai $n=132$ pada taraf signifikansi $5 \%=0.171$. Hal tersebut menunjukkan bahwa nilai $r_{\text {hitung }}>r_{\text {tabel }}$ pada taraf signifikansi 5\%, sehingga diperoleh kesimpulan bahwa $\mathrm{H}_{0}$ ditolak dan $\mathrm{H}_{\mathrm{a}}$ diterima, yaitu terdapat hubungan yang signifikan gaya belajar visual terhadap hasil belajar IPA, terdapat hubungan yang signifikan gaya belajar auditorial terhadap hasil belajar IPA, terdapat hubungan yang signifikan gaya belajar kinestetik terhadap hasil belajar IPA, terdapat hubungan yang signifikan pemanfaatan media belajar terhadap hasil belajar IPA, dan terdapat hubungan secara simultan gaya belajar visual, auditorial, kinestetik, dan pemanfaatan media belajar terhadap hasil belajar IPA.

Koefisien determinasi yang diperoleh pada Tabel 9 di atas yaitu $R_{\text {square }}=0,133$ untuk variabel $\mathrm{X}_{1} \mathrm{Y}$ atau kontribusinya sebesar 13,3\% variabel hasil belajar IPA ditentukan oleh gaya belajar visual dan sisanya sebesar $86,7 \%$ disebabkan oleh faktor lain yang tidak diteliti. $R_{\text {square }}=0,219$ untuk variabel $\mathrm{X}_{2} \mathrm{Y}$ atau kontribusinya sebesar 21,9\% variabel hasil belajar IPA ditentukan oleh gaya belajar auditorial dan sisanya sebesar 78,1\% disebabkan oleh faktor lain yang tidak diteliti. $R_{\text {square }}=0,210$ untuk variabel $\mathrm{X}_{3} \mathrm{Y}$ atau kontribusinya sebesar $21 \%$ variabel hasil belajar IPA ditentukan oleh gaya belajar kinestetik dan sisanya sebesar 79\% disebabkan oleh faktor lain yang tidak diteliti. $R_{\text {square }}=0,062$ untuk variabel $\mathrm{X}_{4} \mathrm{Y}$ atau kontribusinya sebesar 6,2\% variabel hasil belajar IPA ditentukan oleh pemanfaatan media belajar dan sisanya sebesar 93,8\% disebabkan oleh faktor lain yang tidak diteliti. Nilai Adjusted $R_{\text {square }}=0,373$ untuk variabel $\mathrm{X}_{(1,2,3,4)} \mathrm{Y}$ atau kontribusinya sebesar 37,3\% variabel hasil belajar IPA ditentukan oleh gaya belajar visual, auditorial, kinestetik, dan pemanfaatan media belajar serta sisanya sebesar 62,7\% disebabkan oleh faktor lain yang tidak diteliti. 


\section{Pembahasan}

Berdasarkan hasil penelitian penyebaran kuesioner/angket kepada siswa, diperoleh data hipotesis pertama menunjukkan bahwa terdapat hubungan signifikan gaya belajar visual terhadap hasil belajar IPA. Hal ini disebabkan oleh hasil belajar yang baik dapat dipengaruhi oleh kesesuaian cara belajar siswa dalam menyerap materi yang diberikan. Hasil ini didukung oleh hasil temuan yang menunjukkan bahwa ada hubungan yang signifikan gaya belajar visual terhadap hasil belajar siswa (Bire et al., 2014; Sutriani et al., 2018). Berdasarkan hasil penelitian, didapatkan temuan pertama dalam penelitian ini yaitu analisis data mengenai gaya belajar visual terhadap hasil belajar IPA. Penelitian ini menunjukkan bahwa gaya belajar visual merupakan salah satu faktor internal yang dapat memengaruhi hasil belajar IPA siswa. Siswa dengan gaya belajar visual akan mencapai hasil belajar yang optimal apabila menerapkan gaya belajar yang sesuai dengan dirinya (Chen \& Sun, 2012; Khamparia \& Pandey, 2018). Siswa dengan gaya belajar visual berguna mengetahui dan memahami informasi dengan kebutuhan melihat, lemah dalam aktifitas verbal, tidak mudah terganggu oleh keributan namun terkadang kehilangan konsentrasi ketika memerhatikan hal-hal yang mengalihkan pandangannya. Rata-rata gaya belajar visual yang diperoleh pada hasil penelitian siswa kelas VI SD Gugus VI Kecamatan Gerokgak berada pada kategori baik. Hal tersebut menunjukkan ketepatan gaya belajar visual akan menciptakan hasil belajar yang baik dan optimal. Jadi, dapat diketahui bahwa gaya belajar visual berpengaruh positif terhadap hasil belajar.

Temuan kedua menunjukkan bahwa terdapat hubungan signifikan gaya belajar auditorial terhadap hasil belajar IPA. Hal ini disebabkan oleh hasil belajar yang baik dapat dipengaruhi oleh ketepatan cara belajar siswa dalam menyerap materi yang diberikan. Berdasarkan hasil penelitian, didapatkan temuan kedua dalam penelitian ini yaitu analisis data mengenai gaya belajar auditorial terhadap hasil belajar IPA. Penelitian ini menunjukkan bahwa gaya belajar auditorial merupakan salah satu faktor internal yang dapat memengaruhi hasil belajar IPA siswa. Siswa dengan gaya belajar auditorial mudah belajar dengan cara menggunakan media-media belajar yang bersifat audio serta memiliki keunggulan dalam menyerap informasi dengan mendengarkan penjelasan secara langsung apabila guru menjelaskan materi dengan baik dan suasana di sekitar tidak bising atau berisik karena siswa dengan gaya belajar auditorial mudah terganggu apabila keadaan di sekitarnya ribut (Kidd et al., 2020; Mabuchi et al., 2020; Mahayanti et al., 2018). Ketepatan gaya belajar auditorial dapat mempertinggi efektivitas belajar dalam peningkatan capaian hasil belajar siswa (Okur \& Bahar, 2010). Rata-rata gaya belajar auditorial yang diperoleh pada hasil penelitian siswa kelas VI SD Gugus VI Kecamatan Gerokgak berada pada kategori baik. Hal tersebut menunjukkan bahwa ketepatan gaya belajar auditorial akan menciptakan hasil belajar yang baik dan optimal. Jadi, dapat diketahui bahwa gaya belajar auditorial berpengaruh positif terhadap hasil belajar.

Temuan ketiga menunjukkan bahwa terdapat hubungan signifikan gaya belajar kinestetik terhadap hasil belajar IPA. Berdasarkan hasil penelitian, didapatkan temuan ketiga dalam penelitian ini yaitu analisis data mengenai gaya belajar kinestetik terhadap hasil belajar IPA. Hal ini disebabkan karena hasil belajar yang baik dapat dipengaruhi oleh ketepatan cara belajar siswa dalam menyerap materi yang diberikan (Huang, 2019; Rambe \& Yarni, 2019). Penelitian ini menunjukkan bahwa gaya belajar kinestetik merupakan salah satu faktor internal yang dapat memengaruhi hasil belajar IPA siswa. Keadaan kondisi fisik siswa akan berpengaruh pada kelancaran dan kemaksimalan siswa mengikuti proses belajar, sehingga memperoleh hasil belajar yang baik. Keterlibatan menggunakan tubuh secara langsung akan mengakibatkan siswa mudah mengingat fakta serta bersifat permanen atau mudah diingat dalam jangka waktu yang lama. Rata-rata gaya belajar kinestetik yang diperoleh pada hasil penelitian siswa kelas VI SD Gugus VI Kecamatan Gerokgak berada pada kategori baik. Hal tersebut menunjukkan ketepatan gaya belajar kinestetik akan menciptakan hasil belajar yang baik dan optimal. Jadi, dapat diketahui bahwa ketepatan gaya kinestetik berpengaruh positif terhadap hasil belajar.

Temuan keempat menunjukkan bahwa terdapat hubungan signifikan pemanfaatan media belajar terhadap hasil belajar IPA. Berdasarkan hasil penelitian, didapatkan temuan keempat dalam penelitian ini yaitu analisis data mengenai pemanfaatan media belajar terhadap hasil belajar IPA. Hal ini disebabkan oleh hasil belajar yang baik dapat dipengaruhi oleh ketepatan cara belajar siswa dalam menyerap materi yang diberikan. Penelitian ini menunjukkan bahwa pemanfaatan media belajar merupakan salah satu faktor eksternal yang dapat memengaruhi hasil belajar IPA siswa (Hartini et al., 2017; Herayanti et al., 2017; Rahmi et al., 2019; Ristiani Sabat et al., 2018). Media belajar dijadikan sebagai perantara pesan dari guru ke siswa. Melalui media belajar dapat memfokuskan siswa pada saat belajar karena adanya ketertarikan siswa terhadap media belajar yang memberikan gambaran nyata terkait informasi yang diberikan. Media belajar dapat membantu siswa memahami materi pelajaran dengan baik dan pembelajaran menjadi lebih bermakna bagi siswa. Media belajar dapat membantu guru untuk mencapai tujuan pembelajaran yang optimal (Meylinda et al., 2016; Sun et al., 2021). Rata-rata pemanfaatan media belajar yang diperoleh pada hasil penelitian siswa kelas VI SD Gugus VI Kecamatan Gerokgak berada pada 
kategori baik. Hal tersebut menunjukkan bahwa pemanfaatan media belajar dapat memengaruhi pencapaian hasil belajar yang baik dan optimal. Jadi, dapat diketahui bahwa pemanfaatan media belajar berpengaruh positif terhadap hasil belajar.

Temuan kelima yaitu terdapat hubungan yang signifikan gaya belajar visual, auditorial, kinestetik, dan pemanfaatan media belajar terhadap hasil belajar IPA. Permasalahan yang ditemukan salah satunya adalah masih terdapat beberapa siswa yang mendapat nilai kurang dari KKM. Hal ini disebabkan oleh gaya belajar visual, auditorial, kinestetik, dan pemanfaatan media belajar secara bersama-sama dapat memengaruhi hasil belajar siswa. Apabila guru mengenali gaya belajar yang dimiliki oleh siswa dan memanfaatkan media belajar yang sesuai dengan karakteristik siswa, maka hasil belajar siswa menjadi lebih optimal. Penelitian ini menunjukkan bahwa terdapat hubungan antara gaya belajar siswa (visual, auditorial, kinestetik) dan hasil belajar siswa (Dedi et al., 2017; Taiyeb \& Mukhlisa, 2015; Utami \& Gafur, 2015). Terdapat hubungan yang positif dan berarti pemanfaatan media belajar terhadap hasil belajar (Ferdiansyah et al., 2020; Sumilat, 2018). Jadi, dapat diketahui bahwa ada pengaruh positif gaya belajar dan pemanfaatan media belajar terhadap hasil belajar IPA.

Berdasarkan hasil penelitian tersebut, temuan kelima dalam penelitian ini adalah temuan analisis data tentang gaya belajar visual, auditorial, kinestetik, dan pemanfaatan media belajar terhadap hasil belajar IPA. Penguasaan gaya belajar serta ketepatan penggunaan gaya belajar oleh siswa akan sangat membantu siswa memahami informasi dan menyerap materi pelajaran dengan baik, sehingga hasil belajar akan baik. Pada proses pembelajaran, siswa perlu dibantu serta diarahkan dalam mengenali gaya belajar yang sesuai dengan dirinya, sehingga tujuan dari pembelajaran dapat tercapai secara efektif dan menjadi kunci keberhasilan siswa dalam mengikuti kegiatan belajar. Begitu juga dengan pemanfaatan media belajar dalam proses pembelajaran akan membantu siswa memahami pembelajaran dengan baik dan bersemangat mengikuti proses belajar. Oleh karena itu, dalam menjelaskan materi pembelajaran, guru perlu memanfaatkan media belajar (Ferdiansyah et al., 2020; Pamungkas et al., 2018). Asumsi tersebut sesuai dengan hasil penelitian yang telah dilakukan bahwa diperoleh hasil terdapat hubungan yang signifikan gaya belajar visual, auditorial, kinestetik, dan pemanfaatan media belajar terhadap hasil belajar IPA. Dengan demikian, kedua faktor tersebut dapat dijadikan landasan dalam peningkatan hasil belajar yang dilihat berdasarkan gaya belajar siswa dan pemanfaatan media belajar. Jadi, dapat disimpulkan bahwa gaya belajar dan media belajar dapat memberikan pengaruh terhadap peningkatan hasil belajar IPA.

Terdapat beberapa implikasi dari penelitian ini diantaranya yaitu bagi siswa, lebih mengenal gaya belajar dirinya sehingga dapat membangun semangat siswa mengikuti proses belajar mengajar dalam meraih hasil belajar yang optimal. Orang tua siswa lebih meningkatkan perhatian dan pengawasan selama anak belajar di rumah dengan mempertimbangkan faktor lain yang dapat mepengaruhi hasil belajar anak selain materi pelajaran dengan fokus pada pengenalan gaya belajar anak dalam meningkatkan hasil belajarnya Guru lebih memperhatikan gaya belajar siswa dan memahami dengan baik kondisi siswa pada saat menerima informasi melalui pemanfaatan media belajar yang sesuai dengan karakter yang dimiliki oleh siswa.

\section{SIMPULAN}

Hasil belajar sangat penting diperhatikan untuk mmmencapai tujuan pembelajaran yang dilihat berdasarkan faktor yang memengaruhinya, di antaranya gaya belajar dan pemanfaatan media belajar. Hasil belajar memiliki hubungan dengan gaya belajar visual, gaya belajar auditorial, gaya belajar kinestetik, dan pemanfaatan media belajar. Rekomendasi ditujukan kepada siswa agar lebih meningkatkan kesadarannya terkait gaya belajar yang dimilikinya. Dengan demikian, hasil dan tujuan pembelajaran dapat tercapai dengan maksimal sesuai dengan yang diharapkan, Guru hendaknya lebih meningkatkan kembali pengawasan dan perhatian selama proses pembelajaran berlangsung ketika siswa menerima materi pelajaran dengan penerapan gaya belajarnya dan pemanfaatan media belajar yang digunakan guru, sehingga siswa memperoleh hasil belajar yang optimal. Orang tua siswa agar meningkatkan pengawasan terhadap anak pada saat belajar di rumah supaya anak memperoleh hasil belajar yang baik dan optimal.

\section{DAFTAR PUSTAKA}

Agung, A. A. G. (2014). Buku Ajar Metodologi Penelitian Pendidikan. Aditya Media Publishing. Amin, A., \& Suardiman, S. P. (2016). Perbedaan Prestasi Belajar Matematika Siswa Ditinjau dari Gaya Belajar dan Model Pembelajaran. Jurnal Prima Edukasia, 4(1), 12. https: //doi.org/10.21831/jpe.v4i1.7688. 
Astuti, I. A. D., Sumarni, R. A., \& Saraswati, D. L. (2017). Pengembangan Media Pembelajaran Mobile Learning Berbasis Android pada Materi Sifat Koligatif Larutan. JRPK: Jurnal Riset Pendidikan Kimia, 3(1), 57-62. https://doi.org/10.21009/jrpk.072.10.

Audie, N. (2019). Peran Media Pembelajaran Meningkatkan Hasil Belajar Peserta Didik. Prosiding Seminar Nasional Pendidikan FKIP, 2(1), 586-595. https://jurnal.untirta.ac.id/index.php/psnp/article/view/5665.

Bire, A. L., Geradus, U., \& Bire, J. (2014). Pengaruh Gaya Belajar Visual, Auditorial, dan Kinestetik terhadap Prestasi Belajar Siswa. Jurnal Kependidikan: Penelitian Inovasi Pembelajaran, 44(2), 128164. https://doi.org/10.21831/jk.v44i2.5307.

Chen, C. M., \& Sun, Y. C. (2012). Assessing the Effects of Different Multimedia Materials on Emotions and Learning Performance for Visual and Verbal Style Learners. Computers and Education, 59(4), 1273-1285. https://doi.org/10.1016/j.compedu.2012.05.006.

Cholifah, T. N., Degeng, I. N. S., \& Utaya, S. (2016). Pengaruh Latar Belakang Tingkat Pendidikan Orangtua dan Gaya Belajar terhadap Hasil Belajar Siswa pada Kelas IV SDN Kecamatan Sananwetan Kota Blitar. Jurnal Pendidikan, 1(2), 486-491. http://dx.doi.org/10.17977/jp.v1i3.6177.

Dedi, R., Hendrayana, A. S., Erisyani, E., \& Setiana, N. (2017). Pengaruh Motivasi Belajar, Gaya Belajar, dan Kemandirian Belajar terhadap Hasil Belajar Mahasiswa S1 Pgsd Masukan Sarjana Di Upbjj Ut Bandung. EduHumaniora / Jurnal Pendidikan Dasar Kampus Cibiru, 8(2), 163. https://doi.org/10.17509/eh.v8i2.5139.

Dewi, C. A., Khery, Y., \& Erna, M. (2019). An Ethnoscience Study in Chemistry Learning to Develop Scientific Literacy. Jurnal Pendidikan IPA Indonesia, 8(2), 279-287. https://doi.org/10.15294/jpii.v8i2.19261.

Ekayani, P. (2017). Pentingnya Penggunaan Media Pembelajaran untuk Meningkatkan Prestasi Belajar Siswa (Issue March).

Fauyan, M. (2019). Developing Interactive Multimedia Through Ispring on Indonesian Language Learning with The Insights of Islamic Values in Madrasah Ibtidaiyah. Al Ibtida: Jurnal Pendidikan Guru MI, 6(2), 177. https://doi.org/10.24235/al.ibtida.snj.v6i2.4173.

Ferdiansyah, F., Ambiyar, A., Zagoto, M. M., \& Putra, I. E. D. (2020). Pemanfaatan Media Pembelajaran Berbasis E Learning dalam Meningkatkan Hasil Belajar pada Matakuliah Media Pembelajaran Musik. KOMPOSISI: Jurnal Pendidikan, Bahasa Dan Seni, 21(1), 63-72. https: //doi.org/10.24036/komposisi.v21i1.42098.

Hanifah, L. N., \& Mulyaningrum, E. R. (2021). Analisis Gaya Belajar Siswa Kelas X Terhadap Hasil Belajar pada Materi Protista di SMA Negeri 1 Godong. Jurnal Ilmiah Edukasi, 1(1): 113-129. https://doi.org/10.26877/jie.v1i1.7970.

Hartini, S., Misbah, Dewantara, D., Oktovian, R. A., \& Aisyah, N. (2017). Developing Learning Media Using Online Prezi into Materials about Optical Equipments. Jurnal Pendidikan IPA Indonesia, 6(2), 313317. https://doi.org/10.15294/jpii.v6i2.10102.

Herayanti, L., Habibi, H., \& Fuaddunazmi, M. (2017). Pengembangan Media Pembelajaran Berbasis Moodle pada Matakuliah Fisika Dasar. Jurnal Cakrawala Pendidikan, 36(2), 210-219. https://doi.org/10.21831/cp.v36i2.13077.

Huang, T. C. (2019). Do Different Learning Styles Make a Difference when It Comes to Creativity? An Empirical Study. Computers in Human Behavior, 100, 252-257. https: //doi.org/10.1016/j.chb.2018.10.003.

Khamparia, A., \& Pandey, B. (2018). Effects of Visual Map Embedded Approach on Students Learning Performance Using Briggs-Myers Learning Style in Word Puzzle Gaming Course. Computers and Electrical Engineering, 66, 531-540. https://doi.org/10.1016/j.compeleceng.2017.12.041.

Kidd, E., Arciuli, J., Christiansen, M. H., Isbilen, E. S., Revius, K., \& Smithson, M. (2020). Measuring Children's Auditory Statistical Learning via Serial Recall. Journal of Experimental Child Psychology, 200, 104964. https://doi.org/10.1016/j.jecp.2020.104964.

Mabuchi, Y., Aoki, Y., Shibasaki, M., \& Nakata, H. (2020). The relationship Between Cognitive Style and Sensory Gating During Auditory and Somatosensory Tasks. Neuroscience Letters, 738(March), 135354. https://doi.org/10.1016/j.neulet.2020.135354.

Mahayanti, A. A. I., Putra, D. K. N. S., \& Ganing, N. N. (2018). Siswa Kelas IV SD Gugus Ubud Kecamatan Ubud Tahun Pelajaran 2017/2018. 1(1), 11-20. Journal For Lesson And Learning Studies. http://dx.doi.org/10.23887/jlls.v1i1.14619.g8940.

Masturah, E. D., Mahadewi, L. P. P., \& Simamora, A. H. (2018). Pengembangan Media Pembelajaran Pop-Up Book pada Mata Pelajaran IPA Kelas III Sekolah Dasar. Jurnal EDUTECH Universitas Pendidikan Ganesha, 6(2), 212-221. http://dx.doi.org/10.23887/jeu.v6i2.20294.

Meylinda, F., Yuwana, S., \& Sukartiningsih, W. (2016). Pengembangan Media Pembelajaran Keterampilan 
Berbicara Dengan Program Adobe Flash untuk Siswa Kelas V SD. Jurnal Review Pendidikan Dasar: Jurnal Kajian Pendidikan Dan Hasil Penelitian, 2(3). http://dx.doi.org/10.26740/jrpd.v2n3.p256264.

Novitawati, \& Elyanoor, H. (2015). Meningkatkan Hasil Belajar IPA Pada Konsep Energi Panas dan Bunyi Melalui Kombinasi Model Pembelajaran Inkuiri Terbimbing dan Make A Match dengan Menggunakan Media Audioviual pada Siswa Kelas IV SDN Seberang Mesjid 5 Banjarmasin. Jurnal Paradigma, 10(2), 59-65. https://repo-dosen.ulm.ac.id//handle/123456789/17511.

Nurrita, T. (2018). Pengembangan Media Pembelajaran Untuk Meningkatkan Hasil Belajar Siswa. MISYKAT: Jurnal Ilmu-Ilmu Al-Quran, Hadist, Syari'ah Dan Tarbiyah, 3(1), 171-187. https: //doi.org/10.33511/misykat.v3n1.171.

Okur, M., \& Bahar, H. H. (2010). Learning Styles of Primary Education Prospective Mathematics Teachers; States of Trait-Anxiety and Academic Success. Procedia - Social and Behavioral Sciences, 2(2), 3632-3637. https://doi.org/10.1016/j.sbspro.2010.03.565.

Pamungkas, A. S., Ihsanudin, I., Novaliyosi, N., \& Yandari, I. A. V. (2018). Video Pembelajaran Berbasis Sparkol Videoscribe: Inovasi pada Perkuliahan Sejarah Matematika. Prima: Jurnal Pendidikan Matematika, 2(2), 127. https://doi.org/10.31000/prima.v2i2.705.

Pingge, H. D., \& Wangid, M. N. (2016). Faktor Yang Mempengaruhi Hasil Belajar Siswa Sekolah Dasar di Kecamatan Kota Tambolaka. Jurnal Pendidikan Guru Sekolah Dasar, 2(1), 146-167. https: //www.neliti.com/libraries.

Prabanitha, M. I., Sudarma, I. K., \& Dibia, I. K. (2020). Korelasi antara Gaya Belajar dengan Hasil Belajar IPA. Mimbar Ilmu, 25(2), 51. https://doi.org/10.23887/mi.v25i2.25650.

Putri Ningrat, S., Tegeh, I. M., \& Sumantri, M. (2018). Kontribusi Gaya Belajar dan Motivasi Belajar terhadap Hasil Belajar Bahasa Indonesia. Jurnal Ilmiah Sekolah Dasar, 2(3), 257. https://doi.org/10.23887/jisd.v2i3.16140.

Rahmi, M. S. M., Budiman, M. A., \& Widyaningrum, A. (2019). Pengembangan Media Pembelajaran Interaktif Macromedia Flash 8 Pada Pembelajaran Tematik Tema Pengalamanku. International Journal Of Elementary Education, 3(2), 178-185. https://doi.org/10.23887/ijee.v3i2.18524.

Rambe, M. S., \& Yarni, N. (2019). Pengaruh Gaya Belajar Visual , Auditorial , dan Kinestetik terhadap. Jurnal Review Pendidikan Dan Pengajaran, 291-296. https: //journal.universitaspahlawan.ac.id/index.php/jrpp/article/view/486.

Raresik, K. A., Dibia, I. K., \& Widiana, I. W. (2016). Analisis Faktor-Faktor yang Mempengaruhi Hasil Belajar Bahasa Indonesia pada Siswa Kelas V Sd Gugus VI. MIMBAR PGSD Undiksha, 4(1), 3. https://ejournal.undiksha.ac.id/index.php/JJPGSD/article/view/7454.

Rasam, F., \& Sari, A. I. C. (2018). Peran Kreativitas Guru dalam Penggunaan Media Belajar dan Minat Belajar dalam Meningkatkan Prestasi Belajar Peserta Didik SMK di Jakarta Selatan. Research and Development Journal of Education, 5(1), 95-113. https://doi.org/10.30998/rdje.v5i1.3391.

Ristiani Sabat, D., Malaikosa, Y. L., \& Sabat, R. (2018). Efektivitas Media Audio-Visual Berbasis Example Non Example terhadap Kemampuan Berpikir Kritis Mahasiswa Program Studi Pendidikan Biologi. Teori, Penelitian, Dan Pengembangan, 3(4), 504-512. http://dx.doi.org/10.17977/jptpp.v3i4.10810.

Sumilat, J. M. (2018). Pemanfaatan Media Pembelajaran Matematika Interaktif untuk Meningkatkan Hasil Belajar Siswa Di SD Negeri 2 Tataaran. Inventa, 2(1), 40-46. https://doi.org/10.36456/inventa.2.1.a1624.

Sun, L., Ruokamo, H., Siklander, P., Li, B., \& Devlin, K. (2021). Primary School Students' Perceptions of Scaffolding in Digital Game-Based Learning in Mathematics. Learning, Culture and Social Interaction, 28(January 2020), 100457. https://doi.org/10.1016/j.lcsi.2020.100457.

Sutriani, E., Syahrilfuddin, S., \& Noviana, E. (2018). Gaya Belajar Siswa Berprestasi Akademik pada Kelas V Di Sekolah Dasar Negeri 02 Kecamatan Sabak Auh Kabupaten Siak. JURNAL PAJAR (Pendidikan Dan Pengajaran), 2(6), 984. https://doi.org/10.33578/pjr.v2i6.6541.

Taiyeb, A. M., \& Mukhlisa, N. (2015). Hasil Belajar Biologi Siswa Kelas XI IPA SMA Negeri 1 Tanete Rilau. Jurnal Bionature, 16(1), 8-16. https://doi.org/https://doi.org/10.35580/bionature.v16i1.1563.

Tesi Muskania, R., \& Wilujeng, I. (2017). Pengembangan Perangkat Pembelajaran Project-Based Learning untuk Membekali Foundational Knowledge dan Meningkatkan Scientific Literacy. Jurnal Cakrawala Pendidikan, 36(1), 34-43. https://doi.org/10.21831/cp.v36i1.8830.

Utami, P. S., \& Gafur, A. (2015). Pengaruh Metode Pembelajaran dan Gaya Belajar Siswa terhadap Hasil Belajar IPS di SMP Negeri di Kota Yogyakarta. Harmoni Sosial: Jurnal Pendidikan IPS, 2(1), 97-103. https://doi.org/10.21831/hsjpi.v2i1.4622. 